\title{
The stimulatory effect of albumin on luteinizing hormone-stimulated Leydig cell steroid production depends on its fatty acid content and correlates with conformational changes
}

\author{
Roel Melsert ', Octaaf J.M. Bos ${ }^{2}$, Rene F. van der Linden ${ }^{2}$, Marcel J.E. Fischer ${ }^{2}$, \\ Jaap Wilting ${ }^{2}$, Lambert H.M. Janssen ${ }^{2}$, Jos W. Hoogerbrugge ${ }^{1}$ \\ and Focko F.G. Rommerts ${ }^{1}$ \\ ${ }^{\prime}$ Department of Endocrinology and Reproduction, Medical Faculty, Erasmus University Rotterdam, 3000 DR Rotterdam, \\ The Netherlands, and ${ }^{2}$ Department of Pharmaceutical Chemistry, Faculty of Pharmacy, University of Utrecht, \\ 3511 GH Utrecht, The Netherlands \\ (Received 3 May 1991; accepted 9 July 1991)
}

Kcy words: Leydig cell; Testicular fluid; Albumin; Steroid production; Testosterone; Pregnenolone; Neutral-to-base transition; Fatty acids; (Rat)

\section{Summary}

The effects of purified albumin species and albumin fragments $(0.2-1 \% \mathrm{w} / \mathrm{v})$ on short-term $(4 \mathrm{~h})$ steroid secretion by immature rat Leydig cells, in the presence of a maximally stimulating dose of luteinizing hormone $(\mathrm{LH})$, were investigated. Human albumin and the peptic fragment (comprising residues 1-387) enhanced pregnenolone production in isolated rat Leydig cells, whereas chicken albumin and the tryptic fragment (comprising residues 198-585) were not active.

This stimulatory effect of human albumin and the peptic fragment correlated with the potential of these proteins to undergo a pH-dependent neutral-to-base transition as measured by circular dichroism. The tryptic fragment and chicken albumin did not have the potential to undergo such a transition. The $\mathrm{pH}$-dependent conformational changes of albumin and fragments thereof occurred in parallel with a change in the binding affinity for testosterone and pregnenolone.

The fatty acid oleic acid and the drug suramin, only when present in a molar ligand-to-albumin ratio equal to or higher than 2, inhibited the albumin-mediated stimulation of steroid production.

These data show that the stimulatory effects of albumin species on LH-induced Leydig cell pregnenolone production depend on their fatty acid content and correlate with the potential of these molecules to undergo conformational changes. It is unknown via which mechanisms albumin exerts its stimulatory effect, but the LH action through the cyclic AMP pathway seems not to be affected.

Address for correspondence: Focko F.G. Rommerts, Department of Endocrinology and Reproduction, Medical Faculty, Erasmus University Rotterdam, P.O. Box 1738, 3000 DR Rotterdam, The Netherlands.
Abbreviations: T45, the $45 \mathrm{kDa}$ tryptic fragment; $\mathrm{P} 46$, the $46 \mathrm{kDa}$ peptic fragment; $\mathrm{I}$, the ionic strength of a solution; rTF, rat testicular fluid; bFF, bovine follicular fluid; bSA, bovine serum albumin; FCS, foetal calf serum; rS, rat serum; (o)LH, (ovine) luteinizing hormone; NEFA, non-esterified fatty acids; cAMP, adenosine cyclic- $3^{\prime}, 5^{\prime}$-monophosphate. 


\section{Introduction}

In mammalian species, androgens are produced by the Leydig cells in the testes. In the steroidogenic cascade, pregnenolone is the first product of the hormone-dependent cholesterol side-chain cleavage process, whereas androgens, like testosterone, are the final products. The Leydig cells are surrounded by interstitial fluid or lymph (Fawcett et al., 1973; Clark, 1975). This testicular fluid contains many ions and the proteins present in plasma and also locally produced factors (Sharpe, 1979, 1983, 1984; Waites and Gladwell, 1982). It has been shown previously that the rat testicular fluid (rTF) enhances steroid production in isolated rat Leydig cells in the presence of a maximum stimulatory dose of luteinizing hormone ( $\mathrm{LH})$ or in the presence of added $22 R$-hydroxycholesterol, which is an intermediate of the cholesterol side-chain cleavage process (Sharpe and Cooper, 1984; Rommerts et al., 1986; Melsert and Rommerts, 1987). Similar effects were also obtained with foetal calt serum (FCS) and bovine follicular fluid (bFF), but not with adult rat and bovine sera (Mclsert and Rommerts, 1987). Recent studies have shown that an active component in $\mathrm{rTF}$ which gives rise to these stimulatory effects is albumin (Melsert et al., 1988, 1989). Albumin fractions, $0.2-1 \%(\mathrm{w} / \mathrm{v})$, obtained from sera of several other mammalian species (bovine and human) were also effective in stimulating steroid production, whereas chicken serum albumin was not active (Melsert et al., 1989). Other proteins, not structurally related to albumin (e.g. transferrin, ovalbumin, hemoglobin) were inactive (Melsert et al., 1989). Stimulation of steroid production was also observed after perfusion of intact testes with albumin-enriched solutions (Ewing et al., 1976). It is unknown how albumin can enhance the maximally LH-stimulated steroid production.

Albumin is believed to be composed of three contiguous domains, each containing three loops (Kragh-Hansen, 1981; Brown and Shockley, 1982; Peters, 1985). When the $\mathrm{pH}$ is raised from 6 to 9 , both human and bovine serum albumin undergo a conformational change, the so-called neutral-tobase or N-B transition (Foster, 1977; Wilting et al., 1980a, b; Peters, 1985). It has recently been suggested that a conformational change in the albumin molecule may also be involved in the albumin-mediated transport of ligands through membranes of liver cells (Forker and Luxon, 1981, 1983; Weisiger, 1985; Horie et al., 1988; Reed and Burrington, 1989). It was therefore postulated that the stimulatory effect of albumin on the Leydig cells is also connected with changes in the protein conformation.

In this respect we have studied the effect of different types and fragments of albumin on steroid production by Leydig cells. The correlation between the ability to stimulate Leydig cell steroidogenesis and the potential to undergo conformational changes of those proteins was investigated. In addition, the effects of the bound ligands oleic acid and suramin on the stimulatory effect of albumin were examined.

\section{Material and methods}

\section{Reagents}

Pregnenolone and testosterone, obtained from Steraloids, Wilton, NH, U.S.A. and $\left[7-{ }^{3} \mathrm{H}\right]$ pregnenolone $(22.6 \mathrm{Ci} / \mathrm{mmol})$ and $\left[1,2,6,7-{ }^{3} \mathrm{H}\right]$ testosterone $(91.7 \mathrm{Ci} / \mathrm{mmol})$, obtained from Amersham Nederland, Utrecht, The Netherlands, were used without further purification. Bovine serum albumin (Boseral PUR) was obtained from Organon Teknika, Boxtel, The Netherlands. Chicken serum albumin and fatty acid-free bovine serum albumin, both fraction $V$, were supplied by Sigma Chemical Company, St. Louis, MO, U.S.A. Sodium oleate was purchased from Merck, Darmstadt, F.R.G. and suramin was obtained from Bayer, Leverkusen, F.R.G. All other chemicals were of analytical grade.

\section{Preparation of the human albumin and the human albumin fragment solutions}

Human serum albumin was isolated from human plasma according to the method described by Kremer (1982). The human albumin used for all experiments was from one batch. The peptic fragment (the P46 fragment) and the tryptic fragment (the T45 fragment) were obtained as described previously (Bos et al., 1988a, b, c, 1989a). The P46 fragment represents residues 1-387 and therefore comprises domains 1 and 2 of the albu- 
min structure. The T45 fragment corresponds to residues $198-585$ and contains domains 2 and 3 of the albumin structure. All protein solutions were deionized before use as described recently (Bos et al., 1988c).

\section{Leydig cell bioassay}

For the isolation of Leydig cells, immature Wistar rats, substrain $\mathrm{R}$ Amsterdam, were used. The Leydig cells were isolated from 22- to 24day-old rat testes as described previously (Rommerts et al., 1985). The cells were plated in 96-well plates at a concentration of $0.5 \times 10^{5}$ Leydig cells/well in $0.2 \mathrm{ml}$ minimal essential medium (MEM), with Earle's salts, non-essential amino acids, streptomycin $(100 \mu \mathrm{g} / \mathrm{ml})$, penicillin (100 IU $/ \mathrm{ml})$, Fungizone $(0.6 \mu \mathrm{g} / \mathrm{l})$ and $0.1 \%$ $(\mathrm{w} / \mathrm{v})$ bovine serum albumin, fraction $\mathrm{V}$. After 1 $h$, non-attached cells were removed by washing with the same medium. Attached cells were incubated for 3 or $4 \mathrm{~h}$ at $32^{\circ} \mathrm{C}$ and $5 \% \mathrm{CO}_{2} /$ air in MEM that contained the sample to be tested in the absence or presence of LH (ovine LH, 100 $\mathrm{ng} / \mathrm{ml}$ ) and inhibitors of pregnenolone metabolism (Van der Vusse et al., 1974; Melsert et al., 1988). After incubation, the media were collected and stored at $-20^{\circ} \mathrm{C}$. After the steroids had been extracted with ethylacetate (recovery greater than 99\%), the amount of pregnenolone in culture media was measured by radioimmunoassay (Van der Vusse et al., 1975; Themmen et al., 1986). The bioassay is based on the ability of rat testicular fluid or albumin to cause a dose-dependent increase in pregnenolone production by isolated Leydig cells already maximally stimulated by LH (Melsert and Rommerts, 1987; Melsert et al., 1988).

For the determination of cAMP the cells were lysed with $5 \%$ perchloric acid at $4^{\circ} \mathrm{C}$ directly after removal of the medium. The lysate $(200 \mu \mathrm{l})$ obtained was mixed with Tris buffer $(1.1 \mathrm{M}, 20$ $\mu \mathrm{l}$ ), adjusted to $\mathrm{pH} 7$ with $\mathrm{KOH}$, stored at $-20^{\circ} \mathrm{C}$ and assayed for cAMP using a commercial cAMP kit (Amersham Int.).

Measurements of non-esterified fatty acids (NEFA)

For the enzymatic determination of nonesterified fatty acids in various biological fluids and isolated albumins, the NEFA C-test was used (Wako Pure Chemical Industries, Osaka, Japan).
Preparation of albumin-oleate and albumin-suramin complexes

Oleate-albumin complexes were obtained by adding warm solutions of sodium oleate $\left(55^{\circ} \mathrm{C}\right)$ dropwise to solutions of fatty acid-free bovine serum albumin (Lamers and Hulsmann, 1977). Oleate-albumin complexes of molar ratios 0.25 , $0.5,1,2$, and 3 with the albumin concentration being $1.5 \times 10^{-4} \mathrm{M}$ were prepared. In a similar way, suramin-albumin solutions were prepared by adding freshly prepared solutions of suramin to solutions of albumin.

\section{Equilibrium dialysis}

Equilibrium dialysis experiments were carried out with testosterone and pregnenolone as described previously (Bos et al., 1988b, c). The concentrations of human albumin, the T45 fragment, the P46 fragment and chicken albumin were all $6 \times 10^{-5} \mathrm{M}$ and the molar steroid-toprotein ratios were 0.02 . The protein solutions were made in $0.1 \dot{M}$ phosphate or borate buffers with $\mathrm{pH}$ values between 6 and 9 . In the solutions bound and free steroids were measured by liquid scintillation counting. For calculation of the association constants it was assumed that all binding sites on each protein were equivalent and independent (Westphal, 1971; Wilting et al., 1980a).

\section{Circular dichroism (CD)}

Circular dichroic studies of the interaction between testosterone and albumin were performed as described previously (Bos et al., 1988b, c). The albumin concentration was $10^{-4} \mathrm{M}$ and a molar testosterone-to-protein ratio of 1.0 was chosen, because this was found to give suitable signal-tonoise ratios. The observed ellipticities $\left(\theta_{\text {obs }}\right)$ are the differences between the CD spectra of the testosterone-albumin complexes and those of the protein alone at a given wavelength. Molar ellipticities $([\theta])$ were calculated as described previously (Bos et al., 1988b, c).

\section{Results}

Effects of various albumin species on $C A M P$ and steroid production

Addition of fatty acid-frec bovine albumin results in a 3-fold increase in pregnenolone produc- 


\section{TABLE 1}

EFFECT OF BOVINE SERUM ALBUMIN ON BASAL AND LH-STIMULATED PREGNENOLONE AND CYCLIC AMP PRODUCTION BY RAT LEYDIG CELLS

Leydig cells were incubated in the presence of various additions: $1 \%(\mathrm{w} / \mathrm{v})$ fatty acid-free bovine serum albumin (bSA) and $/$ or $100 \mathrm{ng} / \mathrm{ml}$ ovine luteinizing hormone (oLH). After 3 $\mathrm{h}$ the medium was collected for pregnenolone measurement and the cells were lysed for cAMP determination. Values are means $\pm \operatorname{SD}(n=3)$.

\begin{tabular}{lcl}
\hline Additions & $\begin{array}{l}\text { Pregnenolone } \\
\left(\mathrm{pmol} / 0.5 \times 10^{5} \text { cells }\right)\end{array}$ & $\begin{array}{l}\text { cAMP } \\
\left(\mathrm{pmol} / 0.5 \times 10^{5} \mathrm{cells}\right)\end{array}$ \\
\hline None & $0.5 \pm 0.1$ & $7.2 \pm 0.8$ \\
$\mathrm{bSA}$ & $1.7 \pm 0.2$ & $6.7 \pm 1.5$ \\
oLH & $12.1 \pm 0.2$ & $25.4 \pm 2.1$ \\
oLH $+\mathrm{bSA}$ & $32.6 \pm 0.5$ & $27.1 \pm 3.2$ \\
\hline
\end{tabular}

tion in the absence and in the presence of ovine LH (Table 1). For two reasons it is very unlikely that these effects are due to bovine LH which may be present in the bovine albumin preparation used. First, in the absence of oLH there is no effect of albumin on the intracellular cAMP level, and second, albumin further increases Leydig cell pregnenolone production already maximally stimulated with $100 \mathrm{ng} / \mathrm{ml} \mathrm{oLH}$, without an effect on the LH-induced cAMP production (Table 1). To exclude interference from the $\mathrm{LH}$ in the various albumin preparations, all other experiments were done in the presence of this 100 -fold excess of oLH.

Addition of human albumin enhances, in a dose-dependent manner, the pregnenolone production by Leydig cells in the presence of a maximum stimulatory dose of LH (Fig. 1). Similar effects have been obtained with bovine and rat serum albumin, whereas chicken serum albumin was inactive (Melsert et al., 1988, 1989). Steroid production in the presence of $\mathrm{LH}$ was also enhanced by the P46 fragment, whereas the T45 fragment did not stimulate steroid production. The pregnenolone production by Leydig cells was not influenced by various doses of chicken albumin (Fig. 1).

\section{Determination of non-esterified fatty acids}

The amount of latly acids in several biological fluids and albumin preparations was determined in order to establish whether or not fatty acids can explain why albumin in adult rat plasma and bovine plasma and purified chicken albumin does not enhance Leydig cell steroidogenesis (Melsert et al., 1988, 1989). Table 2 gives the molar ratio of fatty acid and albumin for the various biologi-

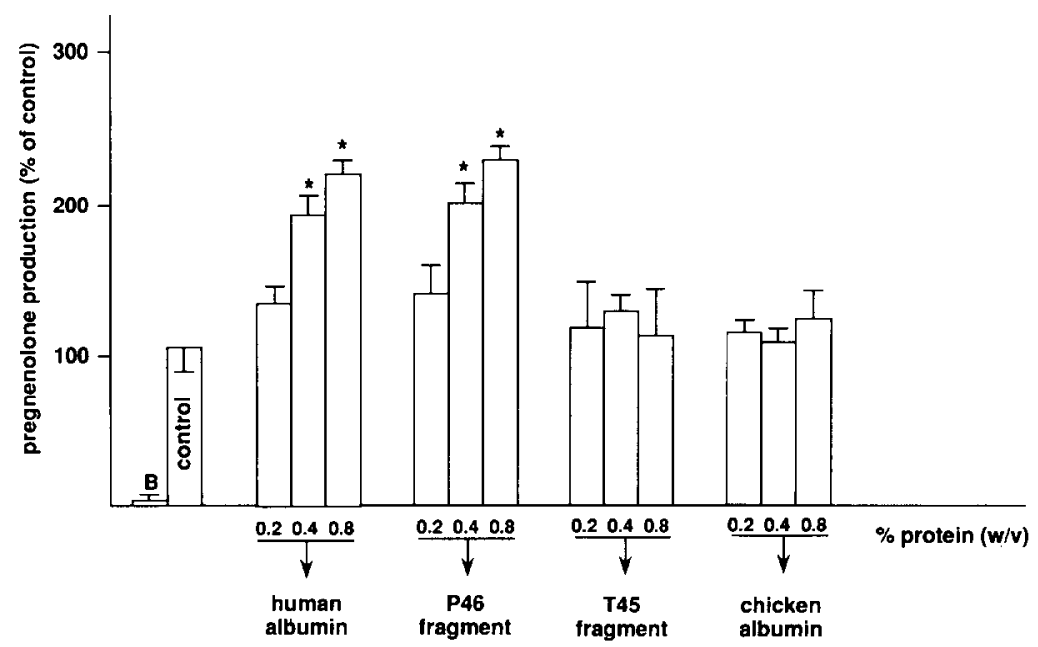

Fig. 1. Effect of human albumin, the P46 fragment, the T45 fragment and chicken albumin on the LH-stimulated pregnenolone production in isolated rat Leydig cells after a $4 \mathrm{~h}$ incubation. Data are expressed as percentage of control (mean \pm SD, $n=4)$. The control is the pregnenolone production in the presence of a maximally stimulatory dose of LH (100 $\mathrm{ng} / \mathrm{ml}) \mathrm{in}$ minimal essential medium (MEM) without further additions $\left(14.4 \mathrm{pmol} / 0.5 \times 10^{5}\right.$ Leydig cells $\left./ 4 \mathrm{~h}\right) . \mathrm{B}$ is the pregnenolone production in the absence of LH $\left(0.6 \mathrm{pmol} / 0.5 \times 10^{5}\right.$ Leydig cells $\left./ 4 \mathrm{~h}\right) .{ }^{*}$ Significantly different from control $(P<0.01$, Student's $t$-test $)$. 
TABLE 2

MOLAR RATIO OF FATTY ACID BOUND TO ALBUMIN FOR VARIOUS FLUIDS AND ISOLATED ALBUMINS

Molar ratio of non-esterified fatty acids bound to albumin for rat serum ( $\mathrm{rS}$ ), rat testicular fluid ( $\mathrm{rTF}$ ), bovine follicular fluid (bFF), foetal calf serum (FCS), chicken albumin, bovine albumin, human albumin, and the human albumin fragments (mean \pm SD for 3-4 determinations).

\begin{tabular}{lc}
\hline Source & $\begin{array}{c}\text { Molar ratio fatty acid } \\
\text { bound to albumin }\end{array}$ \\
\hline rS & $2.41 \pm 0.05^{\mathrm{a}}$ \\
$\mathrm{rTF}$ & $1.13 \pm 0.04^{\mathrm{a}}$ \\
$\mathrm{bFF}$ & $0.90 \pm 0.05^{\mathrm{a}}$ \\
FCS & $0.23 \pm 0.03^{\mathrm{a}}$ \\
Chicken albumin & $0.58 \pm 0.05^{\circ}$ \\
Bovine albumin & $0.64 \pm 0.07$ \\
Human albumin & $0.70 \pm 0.20$ \\
P46 fragment & $<0.7^{\mathrm{b}}$ \\
T45 fragment & $<0.7^{\mathrm{b}}$ \\
\hline
\end{tabular}

a Value corrected for the albumin content of the fluid, on the assumption that all fatty acids are bound to albumin (Sharpe, 1979; Christensen, 1985; Melsert et al., 1988, 1989).

h Not determined, because we did not expect the amount of fatty acid bound to the proteins to change during the purification of the fragments (Bos et al., 1988a, b, c).

cal fluids, bovine albumin, chicken albumin, human albumin, and the human albumin fragments. It is obvious that for all isolated proteins, the molar ratio of fatty acid bound to protein is less than 1. For rat testicular fluid, bovine follicular fluid, and foetal calf serum, this ratio is approximately equal to 1 or less than 1 . However, in rat serum the fatty acid to albumin ratio is 2.4 .

\section{Effects of the ligands oleic acid and suramin in the} presence and in the absence of albumin

Fatty acid-free bovine serum albumin stimulates LH-induced steroid production in a dosedependent manner, giving rise to a 2.5 -fold increase at an albumin concentration of $1 \% \mathrm{w} / \mathrm{v}$ (Fig. 2). Albumin-oleate complexes, with a molar ratio of oleic acid bound to albumin equal to or less than 1, are still active in stimulation of steroid production. The complex is not active anymore, when the molar ratio of fatty acid-to-albumin is 2 (Fig. 2).

Since it is possible that the effect of the various albumin-oleate complexes on the steroid pro- duction in Leydig cells is caused by increasing amounts of unbound fatty acids, the cffects of 5.3 $\mathrm{nM}, 0.12 \mu \mathrm{M}, 1.72 \mu \mathrm{M}$, and $6.36 \mu \mathrm{M}$ oleate on the steroid production, in the absence of albumin were studied. These oleate concentrations correspond to the concentrations of unbound fatty acids that are present at oleate-albumin complexes of increasing molar ratios of $1,3,5$, and 7 , respectively (the albumin concentration being 1.5 $\times 10^{-4} \mathrm{M}$ ) (Spector and Fletscher, 1978). We found that only at the highest concentration of $6.36 \mu \mathrm{M}$ oleate, steroid production was inhibited to approximately $60 \%$ of the control values (results not shown).

Since fatty acids can be metabolized by Leydig cells, the previous data may underestimate the inhibitory effect of fatty acids. We have therefore also investigated the effect of suramin bound to albumin. Suramin was chosen as a ligand, because it cannot be metabolized and is unable to pass through membranes of liver and kidney cells (Vansterkenburg et al., 1989). The level of suramin during the incubation period can therefore be expected to be constant. Preliminary experiments indicated that suramin does not affect the $\mathrm{N}-\mathrm{B}$ transition. Only at a molar ratio of

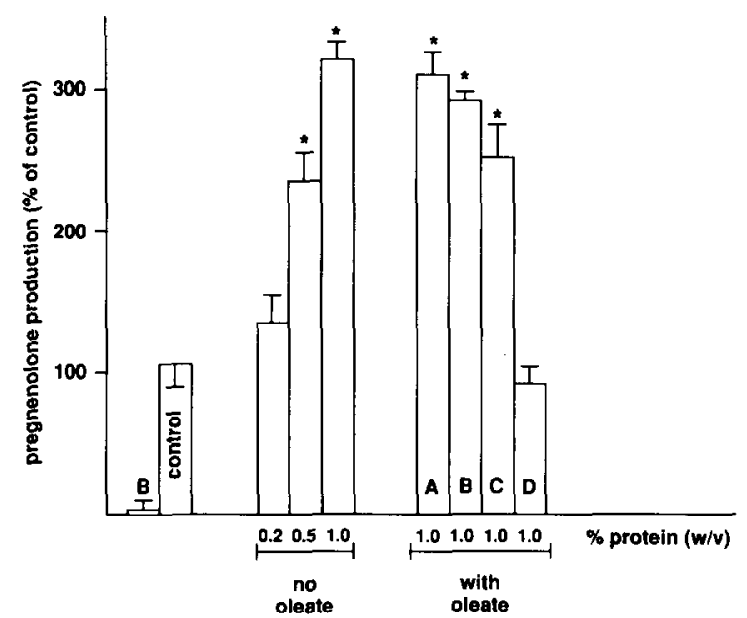

Fig. 2. Effect of oleate-albumin complexes on the LH-stimulated pregnenolone production in isolated rat Leydig cells after a $4 \mathrm{~h}$ incubation in the presence of $1 \%(\mathrm{w} / \mathrm{v})$ fatty acid-free bovine serum albumin. Oleate was present in molar oleate-to-albumin ratios of $0.25(\mathrm{~A}), 0.5(\mathrm{~B}), 1.0(\mathrm{C})$ and 2.0 (D). Data are expressed as percentage of control (mean $\pm \mathrm{SD}$, $n=6$ ). For further conditions see the legend to Fig. 1 . 


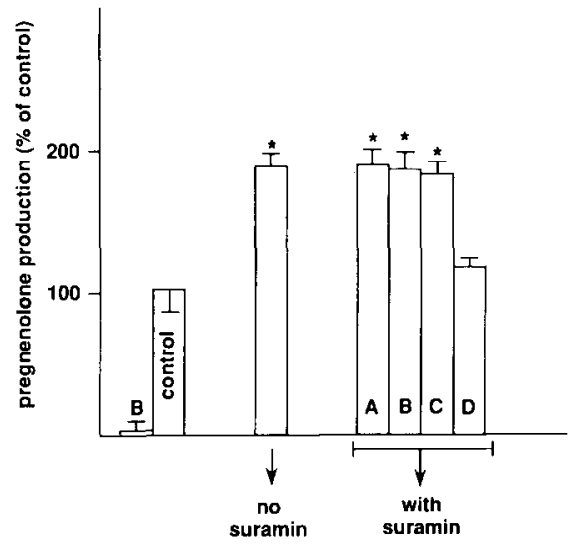

Fig. 3. Effect of suramin-albumin complexes on the LHstimulated pregnenolone production by isolated rat Leydig cclls after a $4 \mathrm{~h}$ incubation in the presence of $1 \%(w / v)$ human serum albumin. Suramin was present in molar suramin-to-albumin ratios of $0.2(\mathrm{~A}), 0.5(\mathrm{~B}), 1.0(\mathrm{C})$, and 2.0 (D). Data are expressed as percentage of control (mean \pm SD, $n=3$ ). For further conditions see the legend to Fig. 1 .

suramin-to-albumin of 2 , the stimulatory effect of albumin on the steroid production has been decreased significantly (Fig. 3). Suramin, in concentrations up to $8.5 \mu \mathrm{M}$ (values corresponding to the concentrations of unbound suramin in the presence of suramin-albumin complexes with a ratio up to 2 , respectively) did not affect Leydig cell steroidogenesis (results not shown).

\section{Conformational aspects}

The various albumin preparations were also characterized with respect to $\mathrm{pH}$-dependent conformational changes as reflected by changes in steroid binding and circular dichroism.

Equilibrium dialysis experiments with steroids were performed in order to investigate the $\mathrm{pH}$ dependency of the steroid binding by intact human and chicken albumin and by the P46 and T45 fragment of human albumin. The $\mathrm{pH}$ dependency of the testosterone binding to these proteins is shown in Fig. 4. The apparent association constants ( $\mathrm{nK}$ ), calculated from the data from the dialysis experiments with testosterone, are given in Table 3. The data show that the binding of steroids to human albumin and the P46 fragment is clearly $\mathrm{pH}$ dependent, whereas the affinity of steroids for chicken albumin and the T45 fragment is $\mathrm{pH}$ independent. Similar data, although

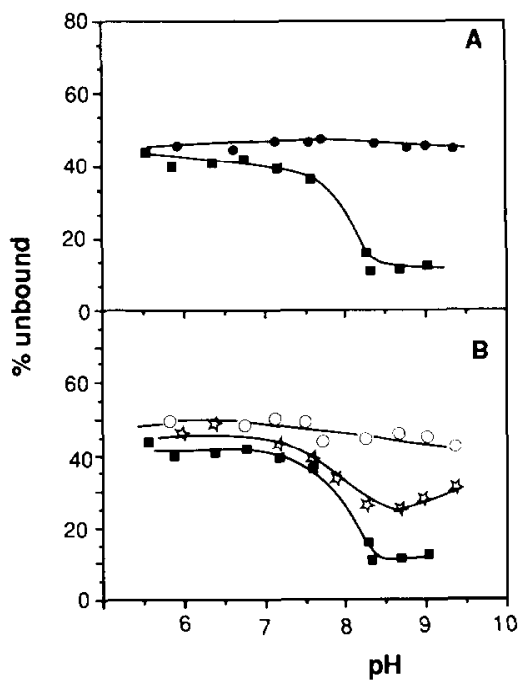

Fig. 4. Effect of the $\mathrm{pH}$ on the binding of testosterone to human albumin, the human albumin fragments and chicken albumin. The percentage of unbound testosterone is plotted as a function of the $\mathrm{pH}$. ( $A$ ) Human albumin ( $\boldsymbol{D}$ ) and chicken albumin $(\bullet)$, ( $B$ ) Human albumin $(\boldsymbol{a})$, the P46 fragment $(B)$ and the T45 fragment $(0)$. Protein concentrations were $6 \times$ $10^{-5} \mathrm{M}$ and testosterone was added in a steroid-to-protein ratio of 0.02 .

less pronounced, were obtained when pregnenolone was used instead of testosterone.

Circular dichroic experiments were performed with human and chicken albumin in order to test whether the $\mathrm{pH}$-dependent changes in steroid binding occur in parallel with conformational changes. The testosterone binding to human albumin induces an extrinsic Cotton effect that has its maximum at $303 \mathrm{~nm}$ (data not shown). Thus, the difference in the CD spectra for testosterone-

\section{TABLE 3}

\section{APPARENT ASSOCIATION CONSTANTS}

The apparent association constants ( $\mathrm{nK}$ ) for the binding of testosterone to various proteins (mean \pm SD for $4-6$ determinations).

\begin{tabular}{llr}
\hline Protein & \multicolumn{2}{l}{$\mathrm{nK \times 10^{-4 } \mathrm { M } ^ { - 1 }}$} \\
\cline { 2 - 3 } & $\mathrm{pH6}$ & $\mathrm{pH} 9$ \\
\hline Human albumin & $1.9 \pm 0.6$ & $14.3 \pm 3.7$ \\
Chicken albumin & $1.8 \pm 0.1$ & $1.9 \pm 0.2$ \\
P46 fragment & $2.1+0.1$ & $4.4 \pm 1.1$ \\
T45 fragment & $1.8 \pm 0.4$ & $2.2 \pm 0.3$ \\
\hline
\end{tabular}




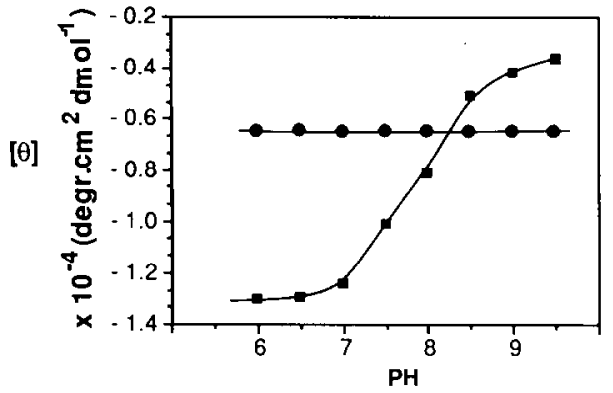

Fig. 5. Circular dichroism experiments with human and chicken albumin. The figure shows the molar cllipticity $[0]$ of the human albumin-testosterone complex ( $\boldsymbol{a})$ and of the chicken albumin-testosterone complex $(\bullet)$ as a function of the $\mathrm{pH}$. The protein concentrations were $10^{-4} \mathrm{M}$ and testosterone was present in a testosterone-to-protein ratio of 1 . Measurements were performed at $303 \mathrm{~nm}$ for human albumin and $312 \mathrm{~nm}$ for chicken albumin in phosphate or borate buffers, $I=0.1$.

albumin complex and for the albumin alone is most pronounced at $303 \mathrm{~nm}$. The effect of the $\mathrm{pH}$ on the molar ellipticity $[\theta]$ is shown in Fig. 5. It can be seen that the molar ellipticity increases with increasing $\mathrm{pH}$, with a maximal effect around pH 8. Testosterone also induces extrinsic Cotton effects, with a maximum at $312 \mathrm{~nm}$ when chicken albumin is used. However, for chicken albumin the molar ellipticity is $\mathrm{pH}$ independent (Fig. 5). In previous work it has been shown that the conformational state of the P46 fragment is clearly $\mathrm{pH}$ dependent, whereas the T45 fragment does not show a $\mathrm{pH}$-dependent conformational change (Bos et al., 1988b, c, 1989a).

\section{Discussion}

Purified albumin preparations from several species, the P46 fragment of human albumin, and also albumin present in rTF, bFF and FCS enhance pregnenolone production in Leydig cells in the presence of a maximally stimulating dose of LH. In contrast, chicken albumin, the T45 fragment of human albumin, and the albumin present in rat and bovine sera are not active when added in similar concentrations of $0.2-1 \% \mathrm{w} / \mathrm{v}$ (Melsert et al., 1988, 1989, and results presented in this study). These data raise at least two important questions. Firstly, why do certain species of albumin further enhance LH-stimulated steroidogenesis, whereas others are inactive? And secondly, how can the activity of these albumin species be inhibited by bound ligands, such as fatty acids? We have tried to answer these two questions in relation with conformational properties of the various albumin species.

It is known that the albumin conformation can be modified by changes in $\mathrm{pH}$ (the so-called neutral-to-hase or N-B transition) or by the addition of ligands such as calcium ions (Peters, 1985). Previous work has shown that between $\mathrm{pH} 6$ and 9 , bovine albumin, human albumin and the P46 fragment show an $\mathrm{N}-\mathrm{B}$ related transition (Wilting et al., 1980a, b; Peters, 1985; Bos et al., 1988b, c, 1989a). In contrast, the T45 fragment and chicken albumin do not show an $\mathrm{N}$ B related transition (Bos et al., 1988c, 1989a, and this paper). These data show that there is a correlation between the stimulatory effect of the type of albumin or fragment and the potential of these proteins to undergo a conformational change.

In a recent paper, we investigated the molecular mechanism of the $\mathrm{N}-\mathrm{B}$ transition in human albumin (Bos et al., 1989a). Since at least five histidine residues in the first domain of the albumin structure are involved in the $\mathrm{N}-\mathrm{B}$ transition, we proposed that the $\mathrm{N}-\mathrm{B}$ transition is induced by the severance of salt bridges between these positively charged histidine residues in domain 1 and anionic residues in domain 2 and 3 . It may be possible that these transitions play a role in the structural changes in albumin molecules upon adsorption to solid surfaces (Norde and Lyklema, 1978; Akaike and Sukarai, 1979; Soderquist and Walton, 1980; Castillo et al., 1984; Norde et al., 1986; Hlady and Andrade, 1988; Reed and Burrington, 1989), or during interaction between albumin and cellular membranes (Weisiger, 1985; Ghinea et al., 1988; Schnitzer et al., 1988). Rccently, Reed and Burrington (1989) presented evidence for conformational changes of the albumin molecule upon binding to intact hepatocytes. It is therefore not unlikely that upon interaction with the Leydig cell membrane, albumin undergoes a conformational change that is somehow transduced through the cell membrane and finally leads to a stimulation of Leydig cell 
steroidogenesis. We have observed that albumin can increase steroid production in the absence and in the presence of LH. Albumin may interact with $\mathrm{LH}$ and this could result in a decreased binding of $\mathrm{LH}$ to its receptor in the presence of bovine serum albumin (Hunter et al., 1982). However, albumin further increases steroid production in the presence of a maximally stimulating dose of $\mathrm{LH}$, without an effect on the gonadotrophin-induced cAMP production (this study). In a previous article we demonstrated that albumin can also enhance steroid production in the presence of $22 R$-hydroxycholesterol (Melsert et al., 1988). These findings indicate that albumin enhances steroid production via a peculiar, yet unknown mechanism not involving $\mathrm{LH}$-activated pathways.

$\Lambda$ hypothetical model for the albumin effect on steroid production in Leydig cells can be described as follows. Albumin interacts with the Leydig cell membrane and this initiates the formation of transient salt bridges between histidines and/or other positively charged residues located on the top of the albumin molecule and negatively charged groups in the membrane matrix. As a result, the internal coherence of the albumin molecule is weakened by the disappearance of salt bridges between the histidines in domain 1 and anionic residues in domain 2 and 3 . This leads to an $\mathrm{N}-\mathrm{B}$ like conformational change in the albumin molecule. Due to the collision interactions between albumin and the cell membrane the membrane matrix may become perturbed. This could result in an increased availability of cholesterol from the membrane or in an increase in membrane phosphoinositide turnover (Langlais and Roberts, 1985). Detailed experiments are necessary to reveal which effect of albumin action is most likely to explain the stimulation of steroid production. The hypothetical collision interaction between albumin and the cell membrane can also account for the relatively high doses of albumin (appr. $10^{-4} \mathrm{M}$ ) which are required before an effect on steroid production can be demonstrated. This model also does not require specific receptors with high affinity for albumin which have not been identified yet (Christensen et al., 1985; Reed and Burrington, 1989).

Several membrane glycoproteins that show affinity for albumin have been isolated from capillary endothelial cells (Ghinea et al., 1988; Schnitzer et al., 1988). These membrane glycoproteins are of interest for their possible role in the translocation of albumin for intravascular to extravascular space. Perhaps, in a similar fashion, one or more glycoproteins in the Leydig cell membrane could interact with albumin. In this respect, Christensen et al. (1985) using electron microscope immunocytochemistry, showed a thin layer of albumin remaining on the surface of Leydig cell in situ after the surrounding albumin was flushed away by perfusion. This retention of albumin was strongest on the microvilli and was absent on the surface of many other cell types that are normally in contact with albumin.

The inhibition of albumin-mediated stimulation of the steroid production by negatively charged ligands poses another question. Fatty acids and suramin, complexed to albumin at ratios higher than 2, inhibit the albumin-mediated stimulation of steroid production. This may be possible by blocking the interaction between albumin and the Leydig cell membrane. King (1987) suggested that binding of fatty acids to albumin molecules is not favourable for the interaction of albumin with the red cell membrane. Similar effects of fatty acids have been reported in the binding properties of lipoproteins to low density lipoprotein (LDL) receptors (Bihain et al., 1989) and in the binding of steroid hormones to specific binding globulins and hormone recepturs (Benassayag et al., 1979, 1986; Martin et al., 1986, 1988; Bregengord et al., 1987; Nunez, 1987; Mooradian et al., 1988). Fatty acids and suramin in the concentrations used do not inhibit the N-B transition of albumin (Peters, 1985).

In various purified albumins the molar NEFAto-protein ratios were found to be less than 1 . In rat serum, however, levels of fatty acids are much higher. This difference in fatty acid content between purified albumins and complete sera can explain why purified human, bovine and rat albumin can enhance steroid production by Leydig cells in the presence of $\mathrm{LH}$, whereas albumin in rat and bovine serum is not active (Melsert et al, $1987,1988,1989)$. The finding that relatively high doses of sera can even exert an inhibition of steroid production in Leydig cells stimulated with 
LH (Melsert et al., 1987) is in accordance with the finding of Meikle et al. (1989) that nonesterified fatty acids (NEFA, such as oleic acid and linoleic acid) can be potent inhibitors of LH-stimulated testosterone production. This inhibition is not caused by an effect of NEFA on the binding of LH to the cell receptor (Meikle et al., 1989). From other studies it is known that fatty acids can alter the structure and functioning of plasma cell membranes (Klausner et al., 1980a, b; MacDonald and MacDonald, 1988) and cells can even be intoxicated (Mather et al., 1979; Wolfe et al., 1980).

In our initial studies with rat testicular fluid (rTF) we started with the hypothesis that rTF contained one ore more biologically active factors not present in rat serum (Sharpe and Cooper, 1984; Rommerts et al., 1986; Melsert et al., 1987). In the following studies we demonstrated with our short-term ( $4 \mathrm{~h})$ bioassay system that serum albumin purified from normal rat rTF accounted for the majority of the steroid stimulating activity in rTF (Melsert et al., 1988, 1989). Since serum and rTF contain similar concentrations of albumin, we suggested that the lack of activity in serum was due to an unidentified serum inhibitor of I eydig cell function (Melsert et al., 1987, 1988). From the present data it can be derived that fatty acids in serum can act as such inhibitors of Leydig cell steroidogenesis. The short-term stimulating effect of rTF on steroid production appears to be mainly due to the action of albumin in rTF, which is 'activated' by the removal of bound fatty acids. These fatty acids may be used as energy substrates for testicular cells (Fritz, 1961).

It cannot be concluded from our studies that biologically active factors, other than albumin (e.g. growth factors), are absent in rTF. For detection of such factors other bioassay systems measuring steroid secretion or $\left[{ }^{3} \mathrm{H}\right]$ thymidine incorporation by isolated cells in long-term cultures $(>4 \mathrm{~h}$ ) are more suitable (Verhoeven and Cailleau, 1985, 1987, 1990; Risbridger et al., 1987; Hedger et al., 199()).

\section{Acknowledgements}

This study was partly supported by the Dutch Foundation for Medical Research (MEDIGON).

\section{References}

Akaike, T. and Sakurai, Y. (1979) A.C.S. Polym. Prep. 20, 581-587.

Benassayag, C., Savu, L., Valette, G., Delorme, J. and Nunez, E.A. (1979) Biochim. Biophys. Acta 587, 227-237.

Benassayag, C., Valette, G., Hassis, J., Raymond, J.P. and Nunez, E.A. (1986) Endocrinology 118, 1-7.

Bihain, B.E., Deckelbaum, R.J., Yen, F.T., Gleeson, A.M., Carpentier, Y.A. and Witte, L.D. (1989) J. Biol. Chem. 264, 17316-17321.

Bos, O.J.M., Fischer, M.J.E., Wilting, J. and Janssen, L.H.M. (1988a) J. Chromatogr. 424, 13-21.

Bos, O.J.M., Fischer, M.J.E., Wilting, J. and Janssen, L.H.M. (1988b) Biochim. Biophys. Acta 953, 37-47.

Bos, O.J.M., Remijn, J., Fischer, M.J.E., Wilting, J. and Janssen, L.H.M. (1988c) Biochem. Pharmacol. 37, 39053909.

Bos, O.J.M., Fischer, M.J.E., Wilting, J. and Janssen, L.H.M. (1989a) J. Biol. Chem. 264, 953-959.

Bos, O.J.M., Fischer, M.J.E., Wilting, J. and Janssen, L.H.M. (1989b) Biochem. Pharmacol. 38, 1979-1984.

Bregengård, C., Kirkegaard, C., Faber, J., Poulsen, S., Siersbaek-Nielsen, K. and Friis, T. (1987) Acta Endocrinol. 116, 102-107.

Brown, J.R. and Shockley, P. (1982) in Lipid Protein Interactions, Vol. 1, pp. 25-68, Wiley and Sons, New York.

Castillo, E.J., Koenig, J.L., Anderson, J.M. and Lo, J. (1984) Biomaterials 5, 319 327.

Christensen, A.K., Komorowski, T.E., Wilson, B., Ma, S.-F. and Stevens. III, R.W. (1985) Endocrinology 116, 19831996.

Clark, R.V. (1975) Anat. Rec. 184, 203-226.

Ewing, L.L., Chubb, C.E. and Robaire, B. (1976) Nature 264, $84-86$.

Fawcett, D.W., Neaves, W.B. and Flores, M.N. (1973) Biol. Reprod. 9, 500-532.

Forker, E.L. and Luxon, B.A. (1981) J. Clin. Invest. 67, $1517-1522$.

Forker, E.L. and Luxon, B.A. (1983) J. Clin. Invest. 72, $1764-1771$.

Foster, J.F. (1977) in Albumin Structure, Function and Uses (Rosenoer, V.M., Oratz, M. and Rothschild, M.A., eds.), pp. 53-84, Pergamon Press, Oxford.

Fritz, I.B. (1961) Physiol. Rev. 41, 52-71.

Ghinea, N., Fixman, A., Alexandru, D., Popov, D., Hasu, M., Ghitescu, L. Eskenasy, M., Simionescu, M. and Siminoescu, N. (1988) J. Cell Biol. 107, 231-239.

Hedger, M.P., Robertson, D.M., De Kretser, D.M. and Risbridger, G.P. (1990) Endocrinology 127, 1967-1977.

Hlady, V. and Andrade, J.D. (1988) Colloids Surfaces 32, 359-363.

Horie, T., Mizuma, T., Kasai, S. and Awazu, S. (1988) Am. J. Physiol. 254, G465-G470.

Hunter, M.G., Magee-Brown, R., Dix, C.J. and Cooke, B.A. (1982) Mol. Cell. Endocrinol. 25, 35-47.

King, M.J. (1987) Transfusion 27, 302-308.

Klausner, R.D., Bhalla, D.K., Dragsten, P., Hoover, R.L. and 
Karnovsky, M.J. (1980a) Proc. Natl. Acad. Sci. U.S.A. 77, 437-441.

Klausner, R.D., Kleinfeld, A.M., Hoover, R.L. and Karnovsky, M.J. (1980b) J. Biol. Chem. 255, 1286-1295.

Kragh-Hansen, U. (1981) Pharmacol. Rev. 33, 17-53.

Kremer, J.M.H. (1982) Vox Sang. 42, 223-224.

Lamers, J.M.J. and Hulsmann, W.C. (1977) J. Mol. Cell. Cardiol. 9, 343-346.

Langlais, J. and Roberts, K.D. (1985) Gamete Res. 12, 183224.

MacDonald, R.C. and MacDonald, R.I. (1988) J. Biol. Chem. $263,10052-10055$.

Martin, M.E., Benassayag, C. and Nunez, E.A. (1988) Endocrinology $123,1178-1186$.

Mather, J.P. and Sato, G.H. (1979) Exp. Cell Res. 124, $215-$ 224.

Meikle, A.W., Benson, S.J., Liu, X.-H., Boam, W.D. and Stringham, J.D. (1989) Am. J. Physiol. 257, E937-E942.

Melsert, R. and Rommerts, F.F.G. (1987) J. Endocrinol. 115, R17-R20.

Melsert, R., Hoogerbrugge, J.W. and Rommerts, F.F.G. (1988) Mol. Cell. Endocrinol. 59, 221-231.

Melsert, R., Hoogerbrugge, J.W. and Rommerts, F.F.G. (1989) Mol. Cell. Endocrinol. 64, 35-44.

Mooradian, A.D., Pamplona, D.M., Viosca, S.P. and Korenman, S.G. (1988) J. Steroid Biochem. 29, 369-370.

Norde, W. and Lyklema, J. (1978) J. Colloid Interface Sci. 66. $266-274$.

Norde, W., MacRitchie, F., Nowicka, G. and Lyklema, J. (1986) J. Colloid Interface Sci. 112, 447-451.

Nunez, E.A. (1987) Tumor Biol. 8, 273-280.

Peters, T. (1985) in Advances in Protein Chemistry, Vol. 37, pp. $161-245$.

Reed, R.G. and Burrington, C.M. (1989) J. Biol. Chem. 264, 9867-9872.

Risbridger, G.P., Drummond, A.E., Kerr, J.B. and De Kretser, D.M. (1987) J. Reprod. Fertil. 81, 617-624.

Rommerts, F.F.G., Molenaar, R. and Van der Molen, H.J. (1985) Methods Enzymol. 109, 275-288.

Rommerts, F.F.G., Hoogerbrugge, J.W. and Van der Molen, H.J. (1986) J. Endocrinol. 109, 111-117.

Schnitzer, J.E., Carley, W.W. and Palade, G.E. (1988) Am. J. Physiol. 254, H425-H437.
Sharpe, R.M. (1979) J. Reprod. Fertil. 55, 365-371.

Sharpe, R.M. (1983) J. Reprod. Fertil. 69, 125-135.

Sharpe, R.M. (1984) Biol. Reprod. 30, $29-49$.

Sharpe, R.M. and Cooper, I. (1984) Mol. Cell. Endocrinol. 41, 247-255.

Soderquist, M.E. and Walton, A.G. (1980) J. Colloid Interface Sci. 75, 386-391.

Spector, A.A. and Fletscher, J.E. (1978) in Disturbances in Lipid and Lipoprotein Metabolism (Dietschy, J.M., Gotto, A.M. and Ontko, J.A., eds.), pp. 229-249, American Physiological Society, Bethesda, MD.

Themmen, A.P.N., Hoogerbrugge, J.W., Rommerts, F.F.G. and Van der Molen, H.J. (1986) J. Endocrinol. 108, 431440 .

Van der Vusse, G.J., Kalkman, M.L. and Van der Molen, H.J. (1974) Biochim. Biophys. Acta 348, 404-414.

Van der Vusse, G.J., Kalkman, M.L. and Van der Molen, H.J. (1975) Biochim. Biophys. Acta 380, 473-485.

Vansterkenburg, E.L.M., Wilting, J. and Janssen, L.H.M. (1989) Biochem. Pharmacol. 38, 3029-3035.

Verhoeven, G. and Cailleau, J. (1985) Mol. Cell. Endocrinol. $40,57-64$.

Verhoeven, G. and Cailleau, J. (1987) Mol. Cell. Endocrinol. $49,137-145$.

Verhoeven, G. and Cailleau, J. (1990) Mol. Cell. Endocrinol. $71,239-251$.

Waites, G.M.H. and Gladwell, R.T. (1982) Physiol. Rev. 62, 624-671.

Weisiger, R.A. (1985) Proc. Natl. Acad. Sci. U.S.A. 82, $1563-$ 1567.

Westphal, U. (1971) in Steroid Protein Interactions (Gross, F., Labhart, A., Mann, T., Samuels, L.T. and Zander, J., eds.), pp. 66-70, Springer-Verlag, Berlin.

Wilting, J., Van der Giesen, W.F., Janssen, L.H.M., Weideman, M.M., Otagiri, M. and Perrin, J.H. (1980a) J. Biol. Chem. 255, 3032-3037.

Wilting, J., '1 Hart, B.J. and De Gier, J.J. (1980b) Biochim. Biophys. Acta 626, 291-298.

Wolfe, R.A., Sato, G.H. and McClure, D.B. (1980) J. Cell Biol. 87, 434-441. 